\title{
The Perceived Motivational Climate Levels of Curling Athletes
}

\author{
Fatih Bedir $^{*}$, Murat Turan ${ }^{2}$ \\ ${ }^{1}$ Department of Sports Sciences, Ataturk University, Erzurum, \\ Turkey \\ ${ }^{2}$ Ministry of Youth and Sports, Ankara, Turkey \\ Study Area: Erzurum, Turkey \\ Coordinates: $39^{\circ} 54^{\prime} 31^{\prime \prime} \mathrm{N} ; 41^{\circ} 16^{\prime} 37^{\prime \prime} \mathrm{E}$
}

\section{Abstract}

The study was aimed to examine the motivational climate perceived in sports of athletes who participated in the Turkish Curling Championship held in Erzurum. The research consisted of two parts of the survey technique. Questions asked about the demographic characteristics of participants and the motivational climate scale perceived in sports. The scale consists of 2 sub-dimensions and 21 items, including a mastery-oriented and performance-oriented motive climate. Data collection tools were filledby 94 athletes (45 men/49 women), who participated in the Turkish Curling Championship held in Erzurum in 2019.

mentioned that when an athlete fails, his motivation is insufficient, and when he succeeds, his motivation is very good. This, in turn, shows the importance of motivation for success in sports. Although leadership and motivation seem to be separate concepts, they are related concepts (Karaküçük \& Yetim, 1996). Therefore, the underlying factor of the athlete's motivation is important. Among these factors, athletes and coaches who are always inside are important factors. Two main sources of motivation in sports can be mentioned: internal and external motivation. Internal motivation is caused by the athlete's inner world, while external motivation is driven by the athlete's external factors (Konter, 1995).

How and by whom athlete motivation is performed is an important issue. It can be said that the motivation of the athlete is easy in terms of specific sports motivation. General Sports motivation is the duty of coaches. A person who will be motivated by General Sports must know the characteristics of an athlete, personality structure, reasons for orientation to sports, family structure, needs, economic status, society, friendship relationships (Dogan, 2015).

Motivational climate the impact of the sports environment on the purpose structure of individuals is another subject area studied in the field of sports and exercise psychology. Solmon \& Boone (1993), notes that perceived motivational climate is an important factor in explaining the athlete's goal orientation, and makes the following definition: it means that athletes are associated with various activities and characterizations of the effect to achieve a sense of success caused by achieving their goals. According to Ames (1992), the motivational climate indicates a structure shaped by the approaches and behaviors of coaches. In other words, the perceived motivational climate arises as to how athletes interpret the element of high performance in sports (Baper, 1996). It is

*Corresponding Author: fatih.bedir@atauni.edu.tr 
environment they are in with the role of external factors such as coaches, family, friends. (Shaw et al., 2005).

Training and competition environments created for athletes are of great importance in terms of their performance. The environments created for these athletes, which have different characteristics from each other, also increase diversity. Some athletes are satisfied with intensive training programs and are more motivated; some athletes want to train or compete in different situations. Mastery climate, which is one of the types of the climate created in a sports environment, consists of factors such as support of the effort, cooperation, skill, and task learning (Roberts et al., 2007). The master climate, which is one of the types of climate created in the sports environment, consists of factors such as support of the effort, cooperation, skill, and task learning. (Roberts \& Ommundsen, 1996; Solmon \& Boone, 1993).

Another of the environments created for athletes is the performance climate. This includes factors such as climate, social comparison, intra-team competition, and punishment. Looking at the studies carried out in this field, it is seen that the master climate is more weighted than the performance Climate from the climates created in the sports environment (Parish \& Treasure, 2003; Roberts \& Ommundsen, 1996; Solmon \& Boone, 1993). The climate of mastery, which takes the forefront of technique and tactics, and the climate of performance based on concrete values such as defeating the opponent, match score, have a huge impact on both the daily lives of athletes and their Sports lives (Altintap 2010). A performance climate is a sports environment that reinforces being superior to your opponent and getting a sense of satisfaction from superiority (Özerkan, 2004). In other words, in a opponent is at the forefront (Ames, 1992).A motive is used in Turkish in the meaning of motive or mobilizer (Soyer et al., 2010). In behavioral sciences, however, it is used for deliberate actions aimed at a goal determined by individual driving forces. Motivation is a set of factors that lead people to a specific behavior (Güney, 200o). Motivation is that people take action with their desires and desires to achieve a specific goal. Each person tends to look for situations that satisfy themselves and give him peace, and avoid situations that bother him. Search and avoidance trends are at the root of motives.

\section{Materials and Methods:}

As a data collection tool in the research; demographic questions asked to obtain information about participants in the first section, the scale of perceived motivational climate in sports in the second part was developed by Walling et al., (1993) Adaptation to Turkish by Toros (2001), consisting of 2 sub-dimensions and a total of 21 items, consisting of a master-oriented and performance-oriented, and was created in the form of 5 Likert. Data collection tools performance climate, beating or outperforming your

were applied to 94 athletes, including 45 men and 49 women, who participated in the Turkish Curling Championship held in Erzurum province in 2019. Factor analysis of the data obtained by Seifriz et al., (1992) and Walling et al., (1993) found the internal consistency coefficients of the scale to be 73 and 84 (performance climate), 80 and 81 (mastery climate).

Statistical analysis conducted within the scope of the research, SPSS V.22 statistics were conducted through the package program. Skewness and Kurtosis tests were performed to determine whether the data provided the prerequisites for parametric tests, and the data showed a normal distribution. The Cronbach Alpha coefficient was also calculated to determine the reliability of the scales. According to the analysis, the reliability of the perceived motivational climate scale in sports was found to be 84 . Descriptive statistics, t-test, and ANOVA tests were used as statistical methods for evaluating the data. The statistical significance level of the analysis was taken as $\mathrm{p}<0.05\left({ }^{*}\right)$.

\section{Results:}

Table 1. Demographic Characteristics Of Participants

\begin{tabular}{llllllr}
\hline Variable & & $\mathrm{N}$ & $\%$ & & $\mathrm{~N}$ & $\%$ \\
\hline Gender & Man & 45 & 47.9 & Woman & 49 & 52.1 \\
Age & $16-20 a g e$ & 57 & 60.6 & $21-25$ age & 27 & 28.7 \\
\multirow{2}{*}{ License Status } & 26-30age & 10 & 10.6 & & & \\
& 7-9 years & 47 & 50 & $4-6$ years & 26 & 27.7 \\
& 21 & 22.3 & & & \\
\hline
\end{tabular}

Table is self-explanatory.

Table-2: Comparison Of The Scores Obtained By Participants In The Motivational Climate Measurement In Sport By Gender Variable (Independent T-test)

\begin{tabular}{lllllll}
\hline Bottom Size & Gender & $\mathrm{N}$ & $\mathrm{X}$ & $\mathrm{ss}$ & $\mathrm{t}$ & $\mathrm{p}$ \\
\hline Mastery-Oriented & Man & 45 & 3.34 & 0.65 & 0.713 & 0.477 \\
Climate & Woman & 49 & 3.25 & 0.52 & & \\
Performance- & Man 45 & 3.56 & 0.61 & 1.31 & 0.192 & \\
Oriented Climate & Woman & 49 & 3.4 & 0.51 & & \\
Total & Man 45 & 3.46 & 0.59 & 1.11 & 0.27 & \\
& Woman & 49 & 3.34 & 0.48 & & \\
\hline
\end{tabular}

As per Table-2, it could be interpreted that the athletes were not differentiated as per the perceived motivational climategendervariable in sports.

Table-3: Comparison Of The Scores Obtained By Participants In The Motivational Climate Measurement In Sport By Gender Variable (Independent T-test)

\begin{tabular}{|c|c|c|c|c|c|c|}
\hline Bottom Size & Age $\quad \mathrm{N}$ & $\mathrm{X}$ & SS & $\mathrm{p}$ & & \\
\hline Mastery-Oriented & (A)16-20 & 57 & 3.22 & .522 & \multirow[t]{4}{*}{0.022} & \\
\hline Climate & (B) $21-25$ & 27 & $3 \cdot 55$ & .710 & & \\
\hline Performance- & (C) $26-30$ & 10 & 3.06 & .399 & & \\
\hline Oriented Climate & Total & 94 & $3 \cdot 3$ & .590 & & \\
\hline \multirow[t]{4}{*}{ Total } & (A)16-20 & 57 & 3.45 & .573 & \multirow[t]{4}{*}{0.188} & $\Xi$ \\
\hline & (B) $21-25$ & 27 & 3.62 & .618 & & $\Sigma \bar{\Xi}$ \\
\hline & (C) $26-30$ & 10 & 3.25 & .227 & & \\
\hline & Total & 94 & 3.48 & .566 & & \\
\hline
\end{tabular}

Ambient Science (2020)

http://www.caves.res.in/

Vol.-07(Sp1):p. 315 
There was a significant difference in the size of only the skill-oriented climate in the lower dimensions of the motivational climate perceived in sports according to the age variable of the participants. Further, the age variable has a significant effect on the perceived motivational climate in sports (Table-3).

Table-4: Comparison Of The Scores Obtained By Participants In The Motivational Climate Measurement In Sport By Gender Variable (Independent T-test)

\begin{tabular}{llllll}
\hline Bottom Size & License & $N$ & X & ss & p \\
\hline Mastery-Oriented & (A)1-3 yrs & 47 & 3.23 & .588 & \\
Climate & (B) 4-6 yrs & 26 & 3.93 & .645 & \\
& (C) 7-9 yrs & 21 & 3.33 & .531 & \\
Performance- & Total & 94 & 3.3 & .590 & \\
Oriented Climate & (A)1-3 yrs & 47 & 3.39 & .582 & \\
Total & (B)-6 yrs & 26 & 3.61 & .606 & \\
& (C) 7-9 yrs & 21 & 3.51 & .459 & \\
& Total & 94 & 3.48 & .566 & \\
\hline
\end{tabular}

This result can be interpreted as the fact that athletes didn't show the difference as per the perceived motivational climate license duration variable in sport.

\section{Discussion:}

This research aims to evaluate the motivational climate levels of Curling players in terms of performance climate and mastery climate.

Looking at the scores that Curling players received from the lower dimensions of the motivational climate scale according to the gender variableno significant difference was found between their values. Despite this, when the average scale score was taken into account, male athletes ' mastery climate and performance climate was in favor of performance climate, in female athletes, it was seen that mastery climate and performance climate were in favor of performance climate.

The fact that both male and female curling athletes were more performance-oriented can be interpreted as a relatively new branch in our country, as athletes in the curling industry have more success indexed. Contrary to our findings; Kelecek et al., (2010) of his work significant differences were found in favor of female athletes in mastery climate $\left(t=2.62 \mathrm{p}=, \mathrm{Oog}^{*}\right)$ as per the scores obtained from the lower dimensions of the motivational climate scale according to the gender variable. Altintap et al., (2012) in a similar study they conducted, female athletes 'mastery climate scores are higher than male athletes' mastery climate scores, no differences were found between the performance climate scores of femaleand maleathletes. Papaioannou (1998), showed that the motivational climate perceived by students was a master climate, and this climate increases the motivation of students.

Chie-der et al., (2003) found in basketball players compared the perceived motivational climate, goal orientation, physical competence, and feelings of trust according to gender, noted that both task orientation and mastery climate scores of female athletes were high in male athletes. Again, similar to these findings, Altyntas (2010) reported the average values of athletes on the perceived motivational climate scale were the highest in the subdimension of mastery climate, the lowest value was obtained from the lower dimension of performance climate. Further in perceived motivational climate mean values highest in female athletes in sub-size of mastery climate, the lowest value was the lower size of the performance climate, while the average values of the master climate of male athletes were the highest and the average values of the performance climate were the lowest. While many studies in the literature show that the scores obtained by individuals are in favor of a master climate, it can be concluded that athletes' performance climate scores are high because they act focused on success in a new branch such as curling.

Considering the scores of the participants obtained from the motivational climate scale in sports, their licensed duration of doing sports; Mastery climate Performance Climate no significant difference was found between their values. Similarly, Altintas et al., (2012) also found that there was no difference between the perceived motivational climate scores of male and female athletes compared to the time they played sports. It can be said that the duration of sports does not affect the perceived motivational climate for both femaleand maleathletes.

According to the results obtained by comparing the scores obtained by participants from the perceived motivational climate scale in sports according to the age variable; 21-25 we can interpret the characteristics represented by the sub-dimension of mastery climate compared to younger individuals in the form that they may had obtained as a result of having a mature point of view and sports experience. In Güven's (2018) work, the difference between perceived motivational climate scale scores in sport according to age variable; no significant difference was found in the result of the T-Test between the master climate sub-sizeand the performance sub-size.

Again Vazou et al., (2006) conducted a study on a group of ages between 12 and 16 who were interested in individual and team sports; no significant difference was found. These findings contrast with the findings in our study, which shown that the age variable does not affect the motivational climate.

Considering the findings and other studies in the literature; It is observed that athletes of different ages and genders give different motivational responses in different branches in terms of mastery and performance climate in motivational climate special. For each athlete, the motivation tools were different and due to different psychological needs, the athlete, his branch and expectations were well analyzed to achieve the desired goals in sports, by using the right motivational sources, it would 
be much more possible for athletes to achieve both the individual goals of the athlete and the common goals of the sport at theoptimal level.

\section{Reference:}

Ames, C. (1992): Classrooms: goals, structures, and student motivation.J. Edu. Psychol., 84(3):261.

Altintas, A. (2010): Sporcularin Hedef Yönelimleri, Algilanan Güdüsel Iklimleri ve Algilanan Fiziksel Yeterliklerinin Cinsiyete ve Deneyim Düzeyine Göre Karsilastirilmasi (Yayinlanmis Yüksek Lisans Tezi). Ankara Üniversitesi Saglik Bilimleri Enstitüsü, Ankara.

Altintas, A. Koruç, P. \& Akalan, C. (2012): Sporcularin Hedef Yönelimleri, Algilanan Güdüsel Iklimleri ve Algilanan Fiziksel Yeterliklerinin Cinsiyete ve Deneyim Düzeyine Göre Karsilastirilmasi. Türkiye Klinikleri J. Sports Sci., 4(1).

Baser, E. (1996): Futbolda Psikoloji ve Basari, (2.Baski), Pub. by: Bagirgan Yayinevi, Ankara, Turkey.

Chie-Der, D., Chen, S., Hung-yu, C. \& Li-Kang, C. (2003). Gender differential in the goal setting, motivation, perceived ability, and confidence sources of basketball players. Sport J., 6(3):3640.

Cüceloglu, D. (2007): Insan ve Davranisi. (16.Baski), Pub. by: Remzi Kitapevi, Istanbul, 230.

Dogan, O. (2015): Spor Psikolojisi. (3.genisletilmis baski), Pub. by: Detay Yayincilik, Ankara, Turkey.

Güney, S. (200o): Davranis Bilimleri, Pub. by: Nobel Yayincilik, Ankara, Turkey.

Güven, S. (2018): Takim Sporlarinda Algilanan Antrenör, Ebeveyn Ve Akran Güdüsel Iklim Faktörlerinin Basari Algisi Üzerindeki Etkisi(Yayinlanmis Yüksek Lisans Tezi). Sivas Cumhuriyet Üniversitesi Saglik Bilimleri Enstitüsü, Sivas.

Karaküçük, S. \& Yetim, A. (1996): Rekreasyon Etkinliklerinde Liderlik ve Fonksiyonlari. Gazi Üniversitesi Beden Egitimi ve Spor Bilimleri Dergisi, 1(1), Ankara, 68.

Kelecek, S., Asçi, F.H. \& Altintas, A. (2010): Elit Erkek Ve Kadin Voleybolcularin Algiladiklari Güdüsel Iklimin, Güdüsel Yönelimlerini Ve Optimal Performans Duygu Durumlarini Belirlemedeki Rolü. Gazi Beden Egitimi ve Spor Bilimleri Dergisi, 15(4):35-47.
Konter, E, (1995): Sporda Motivasyon. Saray Medikal Yayincilik, Izmir, 8-24.

Özerkan, K.N. (2004): Spor Psikolojisine Giris Temel Kavramlar.Pub. by: Nobel Yayin Dagitim, Ankara

Papaioannou, A. (1998): Students' perceptions of the physical education class environment for boys and girls and the perceived motivational climate. Res. Quart. Exer. Ssport, 69(3):267-275.

Parish, L.E., Treasure, D.C. (2003). Physical activity and situational motivation in physical education: influence of the motivational climate and perceived ability. Res. Quart. Exer. Sport, 74:173-182.

Roberts, G.C. \& Ommundsen, Y. (1996): Effect of goal orientation on achievement beliefs, cognitionand strategies in Team Sport. Scandinavian J. Med. Sci. Sport, 6, 46-56.

Roberts, G. C.,Treasure, D. C., Conroy, D. E. (2007). Understanding the dynamics of motivation in sport and physical activity: an achievement goal interpretation, p. 3-10. In G. Tenenbaum \& R.C. Eklund (Ed.), Handbook of Sport Psychology, Third Edition. Pub. by: John Wiley \& Sons.

Sabuncuoglu, Z. (2005). Örgütsel Psikoloji. (5.Baski). Pub. by: Furkan Ofset, Bursa.

Shaw, D. F.,Gorely, P.J. \& Çorban, R.M. (2005). Instant Notes in Sportand Exercise Psychology. Pub. by: Bios Publishers.

Solmon, M.A. \& Boone, J. (1993). The impact of Student Goal Orientation in Physical Education Classes. Res. Quart. Exer. Sport, (64), 418-424.

Soyer, F., Can, Y., Güven, H., Hergüner, G., Bayansalduz, M. \& Tetik, B. (2010): Sporculardaki Basari Motivasyonu Ile Takim Birlikteligi Arasindaki Iliskinin Incelenmesi. Uluslararasi İnsan Bilimleri Dergisi, 7 (1):225-239.

Vazou, S., Ntoumans, N. \& Duda, J.L. (2006). Predicting young athletes motivational indices as a function of their perceptions of the coach- and peer-created climate. Psychol. Sport Exer., 7: 215-233. 